\title{
The effect on the properties of low alloyed bainite ductile iron in oil quenching and isothermal tempering temperature
}

\author{
D.Q. WEI , J. LU \&R . WANG \\ Practice and Experiment Station, Guilin University of Electronic Technology, Guilin, China
}

Keyword: Qil quenching and Isothermal tempering; Ductile iron; Bainite; Temperature

\begin{abstract}
Low alloyed bainite ductile iron can be obtained with the heat treatment technics of oil quench-ing and isothermal tempering. The effects of the austenitizing temperature and the isothermal temperature on the properties of ductile iron are researched. Results show that the matrix microstructure is needle like bainite after the treatment of oil quenching and isothermal tempering and the material mechanical properties of ductile iron get great improvement. The hardness reaches to 56.7 HRC, the impact toughness reaches to $74.5 \mathrm{~J} \cdot \mathrm{cm}-2$, while the tensile strength reaches to 1372.9 $\mathrm{MPa}$. the hardness and tensile strength increases begin and then declines with the rise of the austenitizing temperature. Impact toughness declines gradually with the rise of the austenitizing temperature, and increases with the rise of the isothermal temperature. The better processing parameters in this paper as follows. The austenitizing temperature is $920{ }^{\circ} \mathrm{C}$, while the isothermal temperature is $300{ }^{\circ} \mathrm{C}$.
\end{abstract}

\section{INTRODUCTION}

Ductile iron is an iron-based material developed in the 1950s, its good wear and vibration resistance, excellent mechanical processing performance, low production cost, which is widely used in various fields of national economy [1-3]. Bainite ductile iron strength, hardness, toughness, since the 1970s the advent hailed as one of the major achievements of the last 40 years of iron metallurgy $[4,5]$, The development and production of high-performance shell ductile iron is of great significance.

Oil quenched with temperature isothermal heat treatment process is a patented technology belong to the author[11], the process shown in Figure 1, the sample was placed in a temperature above A1 line austenitizing temperature T1, followed by quenching mechanical oil into the room temperature, until the surface temperature reaches T2 (T2 is a temperature slightly below the Ms, called oil temperature), the temperature T3 which quickly placed under isothermal isothermal furnace to be Bainite transformation. This paper focus on austenitizing temperature and isothermal temperatures, study the impact of these two parameters on bainite ductile properties of the sample.

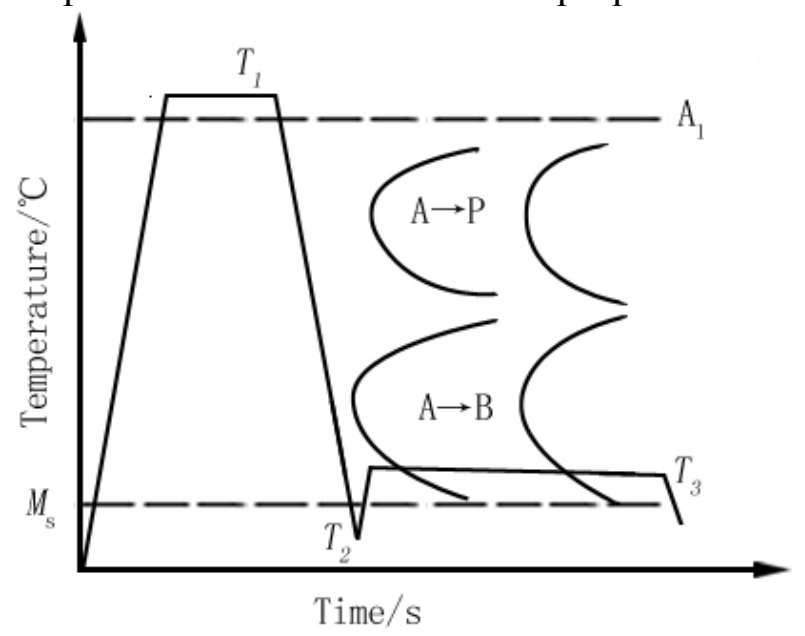

Figure 1. Oil quenching and tempering process with a diagram of the isothermal temperature 


\section{MATERIALS AND METHODS}

\subsection{Sample Preparation}

The Chemical composition of ductile iron is(in wt.\%):Mn, $0.3 ; \mathrm{Mo}, 0.35 ; \mathrm{Cr}, 0.2 ; \mathrm{Cu}, 0.6 ; \mathrm{Si}$, $2.8 ; \mathrm{C}, 3.6 ; \mathrm{P}, \leqslant 0.05 ; \mathrm{S}, \leqslant 0.02 ; \mathrm{Mg}, 0.04$.

Through the medium frequency induction furnace casting $\mathrm{Y}$ type specimen, after processing into the desired sample. When casting, add small amounts of $\mathrm{Mo}, \mathrm{Cr}, \mathrm{Cu}$ alloy elements, iron water polo after birth to turn a small ladle of treatment, the use of alloying elements melt into law. After the chemical composition of ductile iron casting (laboratory component) as shown in Table 1 . The experimental test, cast ductile iron sample hardness of $36.4 \mathrm{HRC}$, impact toughness of $34.5 \mathrm{~J} \cdot \mathrm{cm}-2$, the tensile strength of $691.3 \mathrm{MPa}$.

The cast of Y-type specimen processed into tensile specimens with and without notch impact test specimens, the dimensions shown in Figure 2, Figure 3.

\subsection{Experimental Methods}

The tensile test and impact test specimens are placed RXJ-4-13-temperature box resistance furnace austenitizing process, and then the sample into the SX-4-10-type and low box-type resistance furnace isothermal deal with. Heat treatment process parameters: $\left(880{ }^{\circ} \mathrm{C} \sim 950{ }^{\circ} \mathrm{C}\right) \times 1 \mathrm{~h}+$ oil quenching (oil temperature $\left.180 \sim 220{ }^{\circ} \mathrm{C}\right)+$ isothermal $\left(270 \sim 330{ }^{\circ} \mathrm{C}\right) \times 1 \mathrm{~h}$.

After the heat treatment, in accordance with the relevant standards and operating procedures toughness, strength and hardness testing. Measurement, each set of parameters two samples were averaged for each set of data.

Select the impact fracture of the specimen microstructure morphology was observed with an optical microscope and a JSM-5610LV scanning electron microscope (SEM), and take the scanned image.

\section{EXPERIMENTAL RESULTS AND ANALYSIS}

\subsection{Austenitizing temperature influence on the material properties}

Experiments were selected $900{ }^{\circ} \mathrm{C}, 920{ }^{\circ} \mathrm{C}, 950{ }^{\circ} \mathrm{C}$ three austenitizing temperature, oil quenching oil temperature is $190{ }^{\circ} \mathrm{C}$, isothermal temperature of $300{ }^{\circ} \mathrm{C}$, post-heat treatment hardness, toughness, tensile strength test, and observe the microstructure.

Figure 2, Figure 3 is the austenitizing temperature on hardness, impact toughness and impact rule curve tensile strength. The figure shows that, in the other factors remain unchanged, with the austenitizing temperature, the hardness of the material, after the tensile strength of the first and then decreased,

At $920{ }^{\circ} \mathrm{C}$ hardness value of $56.2 \mathrm{HRC}$, tensile strength up to $1290 \mathrm{MPa}$; toughness is decreased, at $900{ }^{\circ} \mathrm{C}$, the impact toughness of up to $65 \mathrm{~J} \cdot \mathrm{cm}-2$.

Figures 4, 5, 6 are carried out at different temperatures austenitization, after the heat treatment, the iron ball of microstructure. Figure 4 shows, when $900{ }^{\circ} \mathrm{C}$ austenitizing, after oil quenching with isothermal tempering temperature, in addition to lower bainite tissue formation, there are attached to the graphite around the ferrite, it is because the austenitizing temperature lower, making the austenite is not complete, then the matrix structure of austenite and ferrite transformation yet, ferritic transformation occurs during cooling to room temperature while retaining after heat treatment under the matrix contains shellfish martensitic and ferritic, making ductile iron is relatively high toughness, hardness, tensile strength is relatively low. 


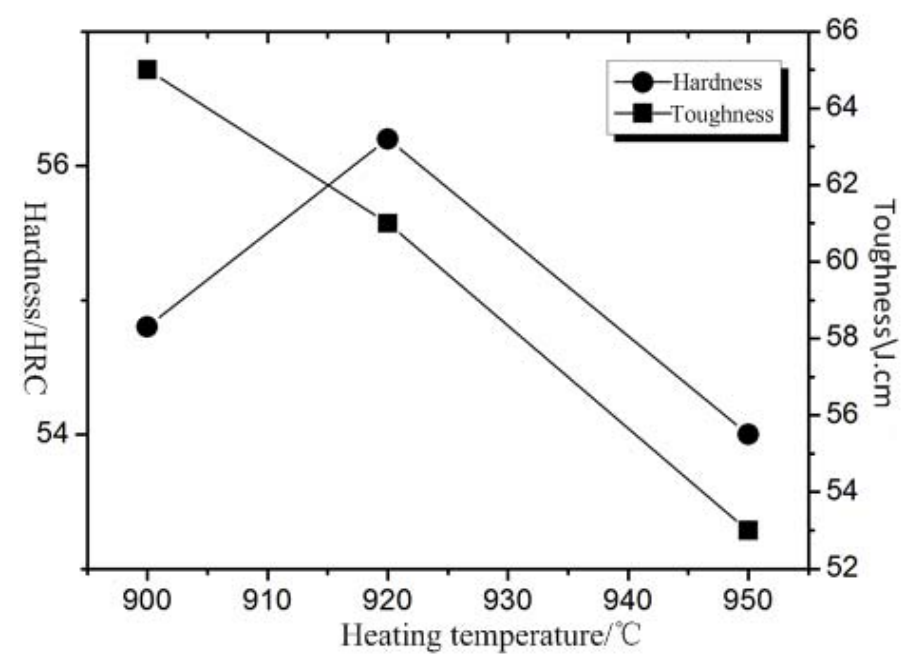

Figure 2. Austenitizing temperature influence on hardness and impact toughness

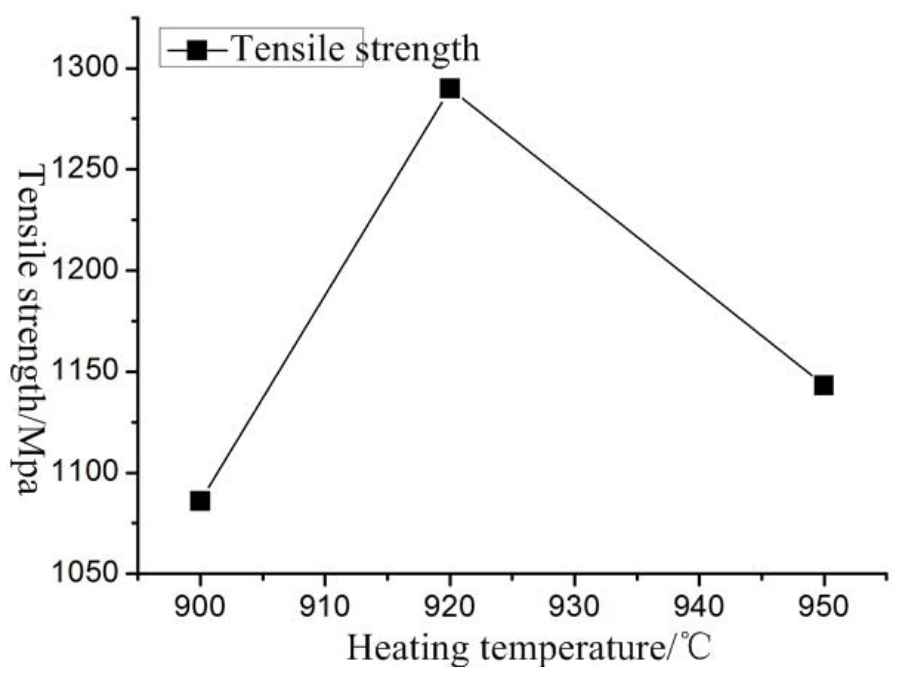

Figure 3. Austenitizing temperature influence on the tensile strength

Figure 5 shows, $920{ }^{\circ} \mathrm{C}$ austenite, organized by the following heat treatment, the main form of lower bainite, more delicate tissue, was thin and long needle. Hardness, high strength, and toughness slightly.

Figure 6 shows that, $950{ }^{\circ} \mathrm{C}$ austenitizing by heat treatment after major tissue formation is lower bainite, but this time the lower bainite thick and short, bamboo-like form. In this state of hardness, strength, toughness is relatively low, because the heating temperature is relatively high, so that higher levels of carbon in austenite, resulting in coarse austenite, which contribute to the stability of austenite, by After the heat treatment to form relatively thick lower bainite, while there are some residual austenite, so that the mechanical properties of the iron ball drop.

In summary, the austenitizing temperature should be appropriate to $920{ }^{\circ} \mathrm{C}$. 


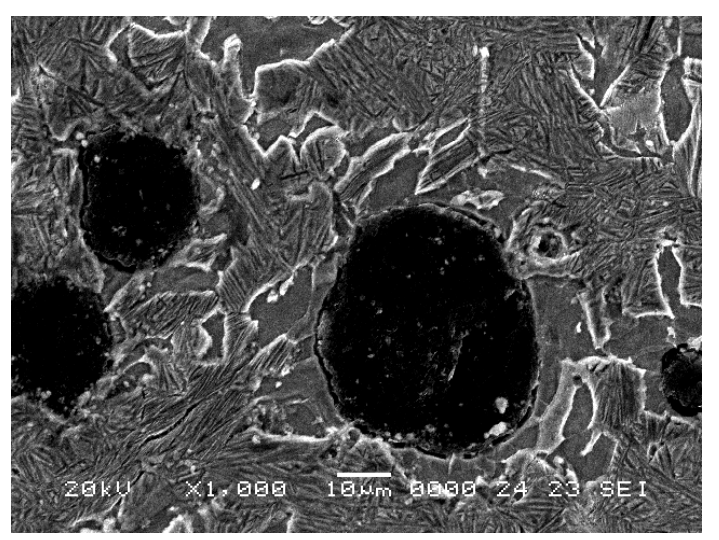

Figure 4. $900{ }^{\circ} \mathrm{C}$ microstructure of the iron ball in Austenitic $(\times 1000)$

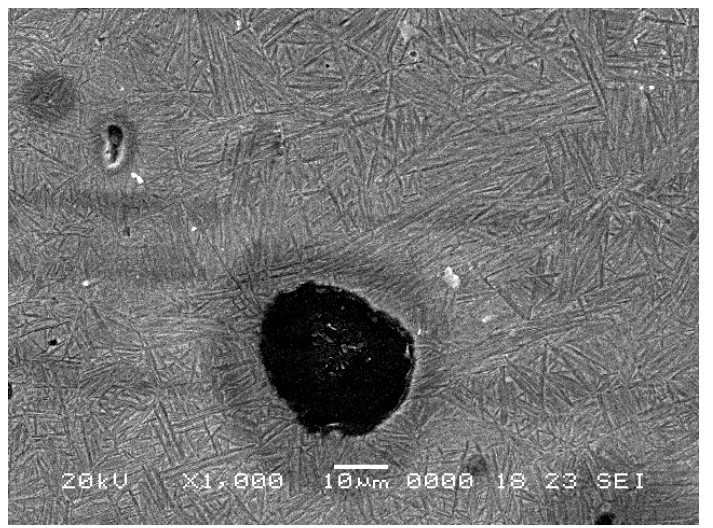

Figure $5.920{ }^{\circ} \mathrm{C}$ microstructure of the iron ball in Austenitic $(\times 1000)$

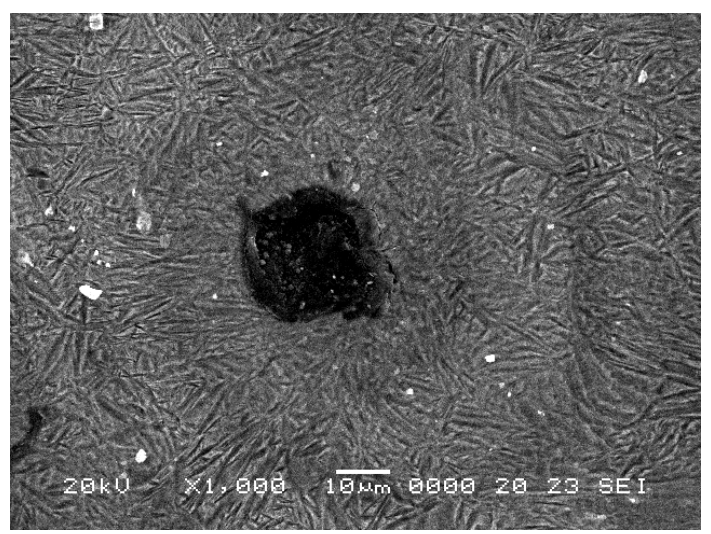

Figure 6. $950{ }^{\circ} \mathrm{C}$ microstructure of the iron ball in Austenitic $(\times 1000)$

\subsection{Isothermal temperature influence on the material properties}

The experiments were selected $270{ }^{\circ} \mathrm{C}, 300{ }^{\circ} \mathrm{C}, 330{ }^{\circ} \mathrm{C}$ as isothermal temperature, austenitizing temperature of $920{ }^{\circ} \mathrm{C}$, the oil temperature was $220{ }^{\circ} \mathrm{C}$, the hardness after heat treatment, toughness, tensile strength test and observation of the metallographic organization

All other factors remain unchanged, with the isothermal temperature, the hardness of the material, after the first and then decreased tensile strength, in the $300{ }^{\circ} \mathrm{C}$ isothermal hardness of 56.7 $\mathrm{HRC}$, tensile strength up to $1307.3 \mathrm{MPa}$; toughness is gradually increased, at $330{ }^{\circ} \mathrm{C}$ isothermal, impact toughness up to $73.5 \mathrm{~J} \cdot \mathrm{cm}-2$. 


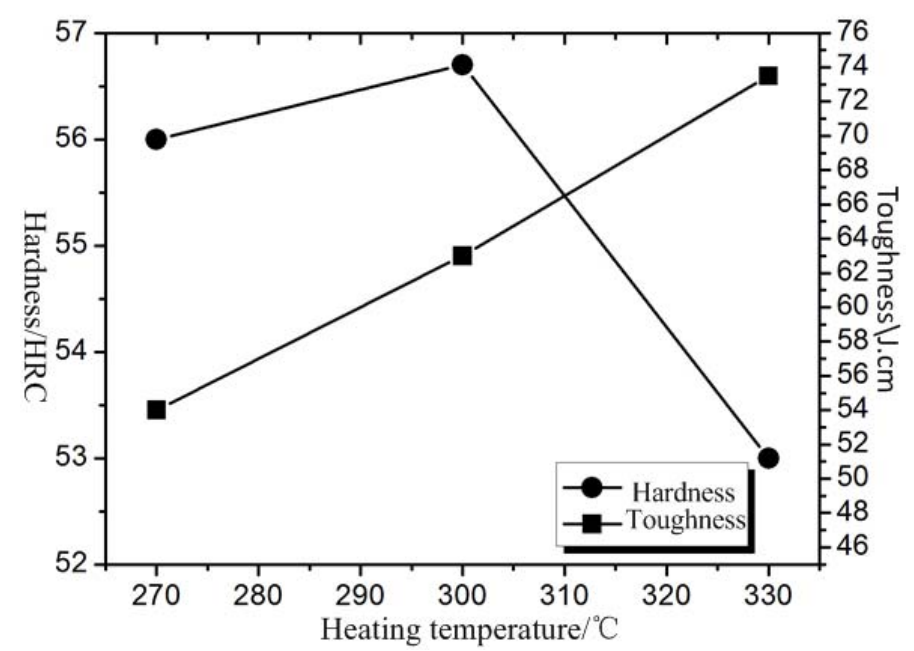

Figure 7 Isothermal temperature influence on hardness and impact toughness

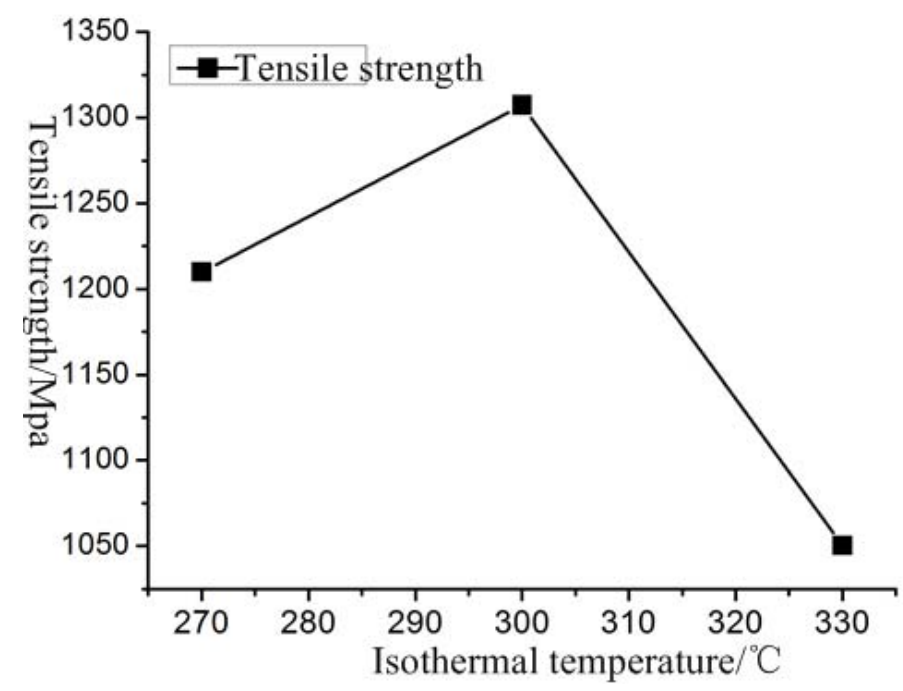

Figure 8 Isothermal temperature influence on tensile strength

Figures 9, 10 and 11 at different temperatures for isothermal heat treatment, ductile iron metallurgical microstructure. Figure 9 and 10 shows that at $270{ }^{\circ} \mathrm{C}, 300{ }^{\circ} \mathrm{C}$ when the isothermal, ductile iron are lower bainite organization, similar to the two forms, organizations are smaller, but the longer the former organization. From the mechanical properties, the hardness of the former than the latter 0.7 HRC, high tensile strength $97.3 \mathrm{MPa}$, high $9 \mathrm{~J} \cdot \mathrm{cm}-2$ toughness, which shows the performance of $300{ }^{\circ} \mathrm{C}$ isothermal treatment at $270{ }^{\circ} \mathrm{C}$ isothermal good performance.

Figure 11 shows that, in the $330{ }^{\circ} \mathrm{C}$ isothermal, ductile iron main organization mixture bainite and upper bainite, organizational thick and short. Isothermal temperature increases, the content of retained austenite increases, and the gradual emergence of the bainite, upper bainite poor performance of the lower bainite, making hardness, tensile strength decreased, but the Bayesian toughness body better, making the impact toughness increased.

The foregoing analysis, isothermal temperature should be appropriate to $300{ }^{\circ} \mathrm{C}$. 


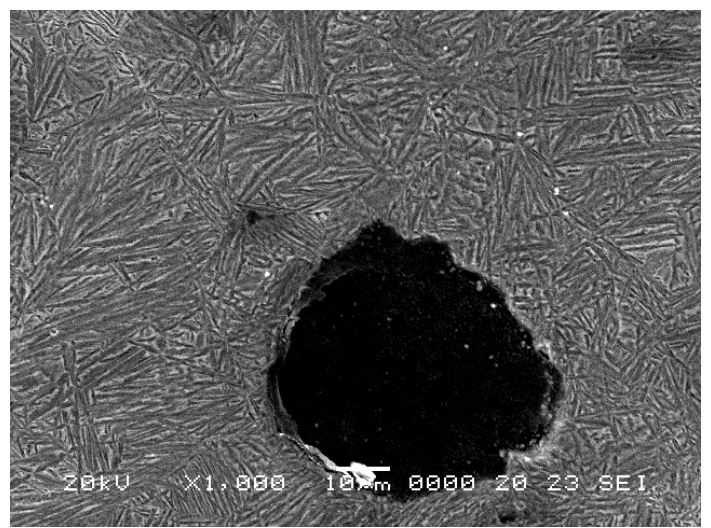

Figure $9270{ }^{\circ} \mathrm{C}$ The Metallurgical Microstructure of ball iron on Isothermal temperature $(\times 1000)$

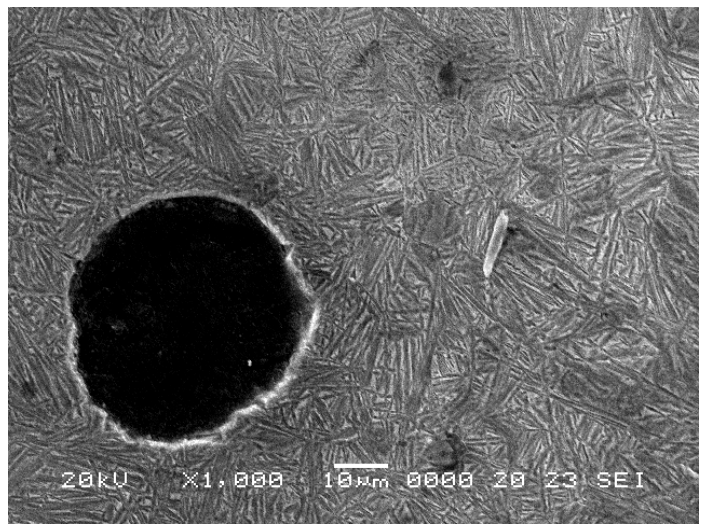

Figure $10300{ }^{\circ} \mathrm{C}$ The Metallurgical Microstructure of ball iron on Isothermal temperature $(\times 1000)$

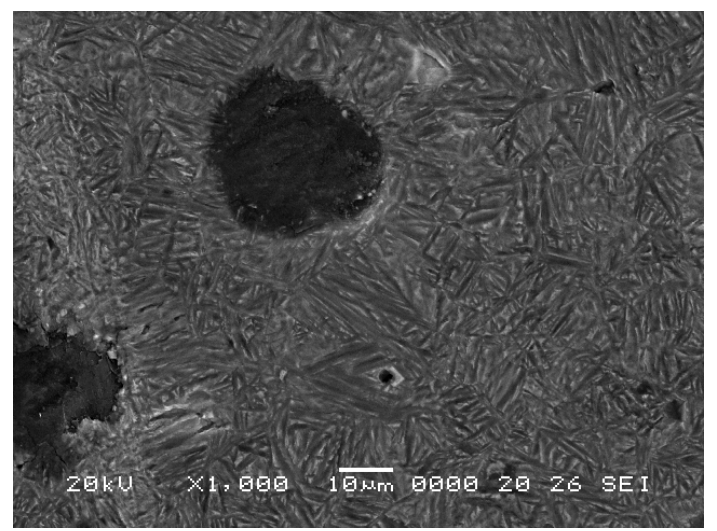

Figure $11330{ }^{\circ} \mathrm{C}$ The Metallurgical Microstructure of ball iron on Isothermal temperature $(\times 1000)$

\section{CONCLUSIONS}

1) After oil quenching with isothermal tempering temperature, the main organization for the bainite ductile iron mechanical properties of fine needle under improved significantly, maximum hardness can reach $56.7 \mathrm{HRC}$, can reach a maximum toughness $74.5 \mathrm{~J} \cdot \mathrm{cm}-2$, the tensile strength can reach $1372.9 \mathrm{MPa}$.

2) With the austenitizing temperature, the ductile iron hardness, tensile strength after the first and then decreased, impact toughness is decreased; With the increasing oil temperature, hardness, tensile strength decreased, impact toughness is increased gradually; with isothermal temperature, the hardness of the material, the tensile strength after the first and then decreased, and toughness is increased gradually.

3) When the austenitizing temperature of $920{ }^{\circ} \mathrm{C}$, the oil temperature of $220{ }^{\circ} \mathrm{C}$, isothermal temperature of $300{ }^{\circ} \mathrm{C}$, after ductile by oil quenching with isothermal tempering temperature, better mechanical properties 


\section{ACKNOWLEDGEMENTS}

This work was financially supported by the research and innovation projects of Graduate(XJYC2012004)

\section{REFERENCES}

[1] Labrecque C\& Gagne M. 1998. Review ductile iron: fifty years of continuous development. Canad. Metall.37:343-378.

[2] Akiyama J. 1967 .Application of ductile iron for civil engineering. Trans AFS75:284-291.

[3] Shanmugam P,Rao PP\&Udupa KR.1994.Effect of microstructure on the fatigue strength of an austempered ductile iron. J Mater Sci;29:4933-4940.

[4] QI Kai. 2009.High temperature plastic deformation behavior of ductile iron research and application. Dalian University of Technology.

[5] Wei B Q,Liang J\&Wu D H. 1999 The ductile fracture toughness of Bainite ductile by Continuous cooling quenching [J]. Journal of Tsinghua University, 39(2) :46-48.

[6] Wei D Q\&Wang R. Low alloy bainitic ductile iron with oil quenching temperature isothermal heat treatment process:china,101200774[P].18 July 2008. 